\begin{tabular}{c|c|c}
\hline $\begin{array}{c}\text { Jurnal Penelitian Keperawatan } \\
\text { Medik }\end{array}$ & Vol. 2 No. 1 & Edition: May - October 2019 \\
\hline & $\frac{\text { http://ejournal.delihusada.ac.id/index.php/JPKM }}{\text { Recepted: } 31 \text { October 2019 }}$ & Acced: 28 October 2019 \\
\cline { 2 - 3 } Received: 16 October 2019 & Revised & \\
\hline
\end{tabular}

\title{
PENGARUH TEKNIK MASSAGE BACK-EFFLEURAGE TERHADAP PENGURANGAN RASA NYERI PERSALINAN KALA I DI KLINIK BERSALIN KURNIA KECAMATAN DELITUA KABUPATEN DELI SERDANG
}

\author{
Suriani, Ela Nuraini, Nurul Aini Siagian \\ Institut Kesehatan Deli Husada, Jl. Besar No.77 Deli Tua \\ e-mail : elanuraini199708@gmail.com
}

\begin{abstract}
This study aims to determine the effect of Back-Effleurage Massage Technique on Reduction of First-Stage Labor Pain in Kurnia Maternity Clinic, Delitua District, Deli Serdang Regency. This study uses a Quantitative Analytical Method with a Quasy-Experimental research design with the One Group Pretest-Posttest approach. Data collection techniques using observation sheets. This BackEffleurage Massage Technique is carried out for 20 minutes/hour during a contraction. The population in this study were 25 pregnant women entering Trimester III. The sampling technique used is the Total Sampling Method. Data analysis using Paired Sample T Test. The results of this study were obtained that the administration of Back-Effleurage Massage Technique on the abdomen at the Kurnia Maternity Clinic can reduce labor pain from mothers who experience moderate pain to mild pain and mothers who experience severe pain to moderate pain. It can be concluded that there is a significant effect with the giving of the Back-Effleurage Massage Technique on the reduction of Stage I labor pain.
\end{abstract}

Keywords: massage, back-effleurage massage, first-stage labor pain

\section{PENDAHUlUAN}

Nyeri persalinan merupakan kondisi fisiologis yang secara umum dialami oleh hampir semua ibu bersalin. Nyeri berasal dari kontraksi uterus dan dilatasi serviks. Dengan bertambahnya baik volume maupun frekuensi kontraksi uterus, nyeri yang dirasakan akan bertambah kuat, puncak nyeri terjadi pada fase aktif, dimana pembukaan lengkap sampai $10 \mathrm{~cm}$ dan berlangsung 4,6 jam untuk primipara dan 2,4 jam untuk multipara (Reeder, Martin \& Griffin, 2011).

Nyeri yang terjadi dapat mempengaruhi kondisi ibu berupa kelelahan, rasa takut, khawatir dan menimbulkan stress. Stress dapat menyebabkan melemahnya kontraksi rahim dan berakibat pada persalinan yang lama. Seorang ibu yang sedang dalam proses persalinan pasti akan mengalami nyeri pinggang persalinan dan berusaha untuk beradaptasi dengan nyeri tersebut. Kemampuan adaptasi dan reaksi ibu dari ibu bersalin terhadap nyeri pinggang persalinan akan dipengaruhi oleh lingkungan dimana ia melahirkan, dukungan sosial yang diterima, dan khususnya teknik pengontrolan nyeri pinggang persalinan (Maryunani,2013).
Nyeri persalinan dapat menyebabkan penderitaan bagi ibu dan kesehatannya. Hal tersebut dapat memiliki efek negative terhadap hubungan ibu dan bayi. Sehingga, banyak ibu yang cemas akan nyeri yang dirasakan saat bersalin. Dalam penggunaan teknik relaksasi, maka pertimbangkan yang harus dilakukan antara lain dengan memperhatikan efektifitas waktu, biaya, aman (tidak membahayakan ibu dan bayi), dan efektif (Cepeda, 2013).

Nyeri persalinan kala 1 fase aktif ini diakibatkan oleh kontraksi rahim yang mulai adekuat dimana kontraksi rahim terjadi 3 sampai 5 kali dalam 10 menit dengan lama kontraksi antara 30 sampai 60 detik. Gerakan kontraksi rahim menyebabkan otot otot dinding rahim mengkerut, menjepit pembuluh darah, vagina dan jaringan lunak di sekitarnya meregang, sehingga terasa nyeri. Keadaan mental si ibu (ketakutan, cemas, khawatir atau tegang ) serta hormone prostaglandin yang meningkat sebagai respon terhadap stress. Intensitas nyeri selama kala 1 fase aktif ini di akibatkan oleh kekuatan kontraksi.

Menurut World Health Organization (WHO) pada tahun 2013, memperkirakan bahwa setiap tahun sejumlah 500.000 orang meninggal akibat 


\begin{tabular}{c|c|c}
\hline $\begin{array}{c}\text { Jurnal Penelitian Keperawatan } \\
\text { Medik }\end{array}$ & Vol. 2 No. 1 & Edition: May - October 2019 \\
\hline & $\frac{\text { http://ejournal.delihusada.ac.id/index.php/JPKM }}{\text { Recepted: 31 October 2019 }}$ & Acced: 28 October 2019 \\
\cline { 2 - 3 } Received: 16 October 2019 & Revised & \\
\hline
\end{tabular}

kehamilan dan persalinan, 99\% kematian tersebut terjadi di Negara berkembang, 50\% kematian tersebut terjadi di Indonesia dan Mesir.

Tahun 2015 merupakan akhir pelaksanaan Millennium Development Goals (MDGs), tetapi mencapai target MDGs diteruskan secara berkesinambungan melalui agenda pembangunan pasca-2015 yang tertuang dalam Sustainable Development Goals (SDGs). Salah satu tujuan SDGs pada urutan ke tiga kesehatan yang baik dan kesejahteraan dengan target capaian tahun 2030 mengurangi angka kematian ibu hingga 70 per 100.000 kelahiran hidup dan mengakhiri kematian bayi dan balita yang dapat dicegah dengan menurunkan angka kematian neonatal setidaknya 12 per 1.000 kelahiran hidup $(\mathrm{KH})$ dan angka kematian balita 25 per $1.000 \mathrm{KH}$ (Suryamin, 2014).

Berdasarkan Kemenkes RI 2015, presentase pertolongan persalinan oleh tenaga kesehatan menunjukkan kecenderungan peningkatan. Terdapat $79,72 \%$ ibu hamil yang mengalami persalinan dengan ditolong oleh tenaga kesehatan dan dilakukan di fasilitas pelayanan kesehatan. Secara nasional, indikator tersebut telah memenuhi target Rencana Strategis $75 \%$.

Dari data yang diperoleh dari Survey Demografi dan Kesehatan Indonesia (SDKI) pada tahun 2013, diperoleh fakta mengejutkan mengenai angka kematian ibu dan anak. Hasil Angka Kematian Ibu (AKI) mencapai 359/100.000 kelahiran hidup.

Berdasarkan Dinkes Provinsi Jawa Tengah 2015, presentase yang terendah adalah di kota Tegal yaitu sebesar 38,91 kelahiran hidup. Salah satu penyebab tingginya Angka Kematian Ibu (AKI) adalah trauma pada ibu dan janin akibat nyeri persalinan. Sedangkan, berdasarkan Dinkes Provinsi Sumatera Utara 2015, AKI yang dilaporkan si Sumatera Utara mengalami penurunan dari 328/100.000 kelahiran hidup menjadi 93/100.000 kelahiran hidup. Upaya mempercepat penurunan AKI dapat dilakukan dengan menjamin agar setiap ibu mampu mengakses pelayanan kesehatan ibu yang berkualitas.
Upaya yang dilakukan Bidan sesuai dengan KEPMENKES No 369 Tahun 2007 tentang standar profesi bidan salah satunya berisi mengenai standar kompetensi bidan selama persalinan seperti pengurangan nyeri tanpa obat. Sedangkan, menurut PERMENKES No 97 Tahun 2014 mengenai pelayanan kesehatan masa melahirkan dalam pasal 14 salah satu aspek dasar yang diberikan kepada ibu bersalin yaitu asuhan sayang ibu dan sayang bayi.

Berbagai upaya dilakukan untuk mengatasi nyeri persalinan. Berat ringannya nyeri yang dirasakan ibu dan bagaimana ibu berespon dalam menghadapi nyeri sangat berpengaruh pada kelangsungan proses persalinan. Nyeri yang terjadi dapat mempengaruhi kondisi ibu berupa kelelahan, rasa takut, khawatir dan menimbulkan stress, Strees dapat menyebabkan melemahnya kontraksi rahim dan berakibat pada persalinan yang lama bahkan kematian ibu.

Menurut Amazine (2017), beberapa cara untuk mengurangi intensitas dan frekuensi nyeri punggung bawah antara lain minum, hindari membungkuk dan mengangkat beban berat, istirahat, gunakan sabuk penopang, hindari pemakaian high heels, bangun secara perlahan, duduk di kursi yang bisa menopang punggung dan tempatkan bantal kecil di belakang punggung bawah, olahraga, serta kompres hangat dan massage.

Dalam penelitian Febriyatie (2013) disebutkan bahwa saat ini banyak ibu hamil menaruh perhatian lebih akan rasa nyeri yang mungkin dihadapi saat persalinan dan juga metode penghilang rasa sakit saat persalinan yang tersedia. Ada dua metode yang dapat meringankan rasa nyeri yaitu metode farmakologi (pemberian obat-obatan analgesik, obat) dan metode nonfarmakologi/alamiah (pijatan, akupuntur, relaksasi, hidroterapi, hipnosis, musik). Metode alamiah ini dapat membantu ibu untuk tetap rileks dan terkendali dalam menghadapi nyeri.

Metode non-farmakologis (secara tradisional) sangat bervariasi yang dapat diterapkan untuk membantu mengurangi rasa nyeri, diantaranya adalah massase/pijatan. Pada umumnya, teknik relaksasi ini cukup efektif dalam 


\begin{tabular}{c|c|c}
\hline $\begin{array}{c}\text { Jurnal Penelitian Keperawatan } \\
\text { Medik }\end{array}$ & Vol. 2 No. 1 & Edition: May - October 2019 \\
\hline & $\frac{\text { http://ejournal.delihusada.ac.id/index.php/JPKM }}{\text { Recepted: 31 October 2019 }}$ & Accised: 28 October 2019 \\
\hline Received: 16 October 2019 & & \\
\hline
\end{tabular}

membantu mengurangi nyeri pinggang persalinan dan relatif aman karena tidak ada efek samping yang ditimbulkan. Prinsip metode ini adalah mengurangi ketegangan ibu sehingga ibu merasa nyaman dan rileks menghadapi persalinan. Metode ini juga dapat meningkatkan stamina untuk mengatasi rasa nyeri dan tidak menyebabkan depresi pernapasan pada bayi yang dilahirkan (Sri Rejeki, 2013).

Pijat dan sentuhan membantu ibu lebih rileks dan nyaman selama persalinan. Sebuah penelitian menyebutkan ibu yang dipijat selama 20 menit setiap jamselama tahapan persalinan akan lebih bebas dari rasa sakit, karena pijat merangsang tubuh melepaskan senyawa endorphin yang merupakan pereda sakit alami dan menciptakan perasaan nyaman. Saat memijat, pemijat harus memperhatikan respon ibu apakah tekanan yang diberikan sudah tepat (Noviyanti, 2016). Umumnya, ada teknik relaksasi yang dilakukan dalam persalinan, yaitu BackEffleurage adalah teknik relaksasi berupa usapan lembut, lambat dan panjang atau tidak putusputus (Pastuty, 2012).

Dalam penelitian yang dilakukan di Amerika Serikat mengungkapkan bahwa sebanyak $84 \%$ ibu yang akan bersalin memilih untuk menggunakan teknik non-farmakologis untuk mengurangi rasa nyeri persalinan. Sebanyak $55,2 \%$ menggunakan teknis pernafasan dan $17,3 \%$ menggunakan teknik pemijatan.

Berdasarkan penelitian yang dilakukan oleh Sri Rejeki (2013), bahwa rentang nyeri yang dirasakam sebelum dilakukannya suatu tindakan adalah 9-10 sebanyak 13 responden $(54,2 \%)$, pada skala 7-8 sebanyak 11 responden (45,8\%). Hal ini dapat diartikan bahwa nyeri yang paling banyak dialami ibu bersalin sebelum dilakukannya tindakan merupakan nyeri berat sehingga nyeri tidak tertahnkan. Setelah dilakukannya teknik Back-Effleurage terjadi penurunan nyeri berat menjadi nyeri sedang sebanyak 18 responden (75\%) pada skala 3-6.

Berdasarkan penelitian yang dilakukan oleh Sri Rejeki (2013), dari data diperoleh usia responden didominasi oleh kategori umur 20 - 35 tahun sebanyak 41 responden dengan persentase sebesar $85,4 \%$. Dalam penelitian ini didapatkan usia responden termuda (minimum) adalah 18 tahun $(4,2 \%)$ dan usia tertua (maximum) adalah 40 tahun $(2,1 \%)$. Karena usia tersebut merupakan usia produktif, wanita produktif memiliki arti yakni suatu keadaan wanita yang telah cukup umur untuk bisa menghasilkan keturunan atau hamil. Usia normal wanita produktif yakni 15-45 tahun, karena pada usia tersebut organ tubuh wanita yang disebut rahim telah mampu untuk menghasilkan indung telur di dalam rahimnya dan berproduksi.

Berdasarkan penelitian yang dilakukan oleh Sri Rejeki (2013), diketahui bahwa intensitas persalinan (paritas) responden didominasi oleh kelompok primipara atau kehamilan/kelahiran pertama kali sebanyak 25 responden dengan persentase $52,1 \%$. Multipara ada 23 responden dengan persentase $47,9 \%$. Paritas merupakan intensitas persalinan atau juga dapat didefinisikan banyaknya kelahiran hidup yang dimiliki seorang wanita. Dari hasil penelitian juga dapat dijelaskan bahwa responden primipara cenderung lebih banyak mengalami nyeri berat dibanding responden multipara, ini didukung dengan nilai rata-rata (mean) pada primipara sebesar 8,80 lebih besar dari nilai (mean) multipara yaitu 8,35.

Berdasarkan Survey pendahuluan yang dilakukan oleh peneliti pada bulan Februari di Klinik Kurnia Ningsih, telah didapatkan data ibu bersalin dari bulan Desember hingga Februari berjumlah 30 ibu bersalin. Dari 30 ibu bersalin didapat 15 ibu bersalin yang melakukan Teknik Massage Back-Effleurage. Dan dari 15 ibu bersalin tersebut didapatkan hasil ada penurunan nyeri persalinan pada kala I.

Berdasarkan latar belakang diatas, maka penulis tertarik untuk melakukan penelitian tentang "Pengaruh Teknik Massage BackEffleurage Terhadap Pengurangan Rasa Nyeri Persalinan Kala I di Klinik Bersalin Kurnia Kecamatan Delitua Kabupaten Deli Serdang Tahun 2019".

\section{METODE}

Jenis penelitian yang dipakai dalam penelitian ini adalah analitik kuantitatif dengan desain penelitian Quasy-Eksperimen. QuasyEksperimen dalam penelitian ini menggunakan 


\begin{tabular}{c|c|c}
\hline $\begin{array}{c}\text { Jurnal Penelitian Keperawatan } \\
\text { Medik }\end{array}$ & Vol. 2 No. 1 & Edition: May - October 2019 \\
\hline & $\frac{\text { http://ejournal.delihusada.ac.id/index.php/JPKM }}{\text { Accepted: 31 October 2019 }}$ & Revised: 28 October 2019 \\
\hline Received: 16 October 2019 & & \\
\hline
\end{tabular}

jenis desain satu kelompok. Desain ini juga disebut dengan desain One Group PretestPosttest.

Penelitian ini dilakukan di Klinik Bersalin Kurnia Kecamatan Deli Tua Kabupaten Deli Serdang dan dilaksanankan pada bulan Maret sampai bulan Mai. Populasi dalam penelitian ini adalah seluruh Ibu Hamil yang memasuki Trimester III, dengan jumlah sampel 25 responden menggunakan teknik Total Sampling.

Alat pengumpulan data yang digunakan adalah wawancara dan lembar observasi pre dan pre intervensi (pengukuran nyeri menggunakan Numeric Rating Scale). Analisis data untuk membuktikan hipotesa yaitu menggunakan Uji Paired Sample T Test.

\section{HASIL DAN PEMBAHASAN}

Berdasarkan hasil penelitian didapatkan ibu yang berusia 18-20 Tahun sebanyak 9 orang (36\%), usia 21-23 Tahun sebanyak 2 orang (8\%), usia 24-26 Tahun sebanyak 7 orang (28\%), usia 27-29 Tahun sebanyak 4 orang (16\%), dan usia 30-32 Tahun sebanyak 3 orang (12\%). Dalam penelitian ini didapatkan usia responden yang termuda adalah 18 Tahun, dan usia responden yang tertua adalah 32 Tahun.

Tabel 1. Karakteristik Responden

\begin{tabular}{lcc}
\hline \multicolumn{1}{c}{ Umur } & F & $\mathbf{( \% )}$ \\
\hline 18-20 Tahun & 9 & 36 \\
21-23 Tahun & 2 & 8 \\
24-26 Tahun & 7 & 28 \\
27-29 Tahun & 4 & 16 \\
30-32 Tahun & 3 & 12 \\
\hline TOTAL & 25 & 100 \\
\hline
\end{tabular}

Usia ibu merupakan salah satu faktor resiko yang berhubungan dengan kualitas kehamilan atau berkaitan dengan kesiapan ibu dalam reproduksi. Usia kurang dari 20 tahun, alat-alat reproduksi belum matang sehingga sering timbul komplikasi persalinan. Umur lebih dari 35 tahun berhubungan dengan mulainya terjadi regresi selsel tubuh berhubungan terutama dalam hal ini adalah endometrium. Umur ibu yang lebih muda memiliki sensori nyeri yang lebih intens dibanding dengan ibu yang memiliki umur yang lebih tua.
Umur muda cenderung dikaitkan dengan kondisi psikologis yang masih labil yang memicu terjadinya kecemasan sehingga nyeri yang dirasakan semakin lebih kuat. Umur juga dipakai sebagai salah satu faktor dalam menentukan toleransi terhadap nyeri (Hutagalung, 2012).

Berdasarkan penelitian yang dilakukan oleh Sri Rejeki (2013), dari data diperoleh usia responden didominasi oleh kategori umur 20 - 35 tahun sebanyak 41 responden dengan persentase sebesar $85,4 \%$. Dalam penelitian ini didapatkan usia responden termuda (minimum) adalah 18 tahun $(4,2 \%)$ dan usia tertua (maximum) adalah 40 tahun $(2,1 \%)$. Karena usia tersebut merupakan usia produktif, wanita produktif memiliki arti yakni suatu keadaan wanita yang telah cukup umur untuk bisa menghasilkan keturunan atau hamil. Usia normal wanita produktif yakni 15-45 tahun, karena pada usia tersebut organ tubuh wanita yang disebut rahim telah mampu untuk menghasilkan indung telur di dalam rahimnya dan berproduksi.

Berdasarkan hasil penelitian, didapatkan untuk Paritas didapatkan ibu yang Primipara atau Kehamilan pertama sebanyak 11 orang (44\%), dan ibu yang Multipara atau yang sudah berulang mengalami kehamilan sebanyak 14 orang (56\%). Dalam penelitian ini didapatkan lebih banyak ibu yang Multipara dibandingkan dengan ibu primipara.

Tabel 2. Karakteristik Paritas Ibu

\begin{tabular}{lcc}
\hline Paritas & F & (\%) \\
\hline Primipara & 11 & 44 \\
Multipara & 14 & 56 \\
\hline TOTAL & 25 & 100 \\
\hline
\end{tabular}

Paritas adalah jumlah anak yang dilahirkan oleh ibu. Sampai dengan paritas tiga, rahim ibu bisa kembali seperti sebelum hamil. Setiap kehamilan rahim mengalami pembesaran, terjadi peregangan otot-otot rahim selama 9 bulan kehamilan. Akibat regangan tersebut elastisitas otot-otot rahim tidak kembali seperti sebelum hamil setelah persalinan. Semakin sering ibu hamil dan melahirkan, semakin dekat jarak kehamilan dan kelahiran, elastis uterus semakin terganggu, akibatnya uterus tidak berkontraksi 


\begin{tabular}{c|c|c}
\hline $\begin{array}{c}\text { Jurnal Penelitian Keperawatan } \\
\text { Medik }\end{array}$ & Vol. 2 No. 1 & Edition: May - October 2019 \\
\hline & $\frac{\text { http://ejournal.delihusada.ac.id/index.php/JPKM }}{\text { Revised: 28 October 2019 }}$ & Accepted: 31 October 2019 \\
\cline { 2 - 3 } & Received: 16 October 2019 & \\
\hline
\end{tabular}

secara sempurna dan mengakibatkan perdarahan pasca kehamilan (Hutagalung, 2012).

Berdasarkan penelitian yang dilakukan oleh Sri Rejeki (2013), diketahui bahwa intensitas persalinan (paritas) responden didominasi oleh kelompok primipara atau kehamilan/kelahiran pertama kali sebanyak 25 responden dengan persentase $52,1 \%$. Multipara ada 23 responden dengan persentase $47,9 \%$. Paritas merupakan intensitas persalinan atau juga dapat didefinisikan banyaknya kelahiran hidup yang dimiliki seorang wanita. Dari hasil penelitian juga dapat dijelaskan bahwa responden primipara cenderung lebih banyak mengalami nyeri berat dibanding responden multipara, ini didukung dengan nilai rata-rata (mean) pada primipara sebesar 8,80 lebih besar dari nilai (mean) multipara yaitu 8,35.

Berdasarkan hasil penelitian ini disimpulkan hipotesa penelitian diterima, ini dapat dibuktikan dengan menggunakan Uji Paired Sampel T Test. Dalam hal ini berlaku ketentuan bahwa nilai statistic uji lebih besar dari nilai tabel, atau nilai tingkat kemaknaan yang diperoleh $\mathrm{p}<\mathrm{a}$ yaitu dengan kemaknaan Ha diterima dan Ho ditolak, sehingga didapat bahwa ada Pengaruh Teknik Massage Back-Effleurage Terhadap Pengurangan Rasa Nyeri Persalinan Kala I.

Tabel 3. Pengaruh Teknik Massage BackEffleurage Terhadap Pengurangan Rasa Nyeri Persalinan Kala I

\begin{tabular}{|c|c|c|c|c|}
\hline Variabel & Mean & $\mathbf{N}$ & SD & Sig \\
\hline \multicolumn{5}{|c|}{ Teknik Massage } \\
\hline $\begin{array}{c}\text { Pretes } \\
\text { Eksperimen }\end{array}$ & 3.72 & 25 & 0.458 & \\
\hline $\begin{array}{c}\text { Postes } \\
\text { Eksperimen }\end{array}$ & 2.24 & 25 & 0.436 & 0.00 \\
\hline $\begin{array}{l}\text { Beda pretes- } \\
\text { postes }\end{array}$ & 1.48 & 25 & 0.510 & \\
\hline
\end{tabular}

Back-Effleurage adalah teknik pijatan yang dilakukan untuk membantu mempercepat proses pemulihan nyeri persalinan dengan menggunakan sentuhan tangan pada perut klien secara perlahan dan lembut untuk menimbulkan efek relaksasi. Pada saat proses persalinan memasuki Kala I, jika teknik ini dilakukan cukup efektif dapat membantu mengurangi rasa nyeri. Prinsip metode ini adalah mengurangi ketegangan ibu sehingga ibu merasa nyaman dan rileks menghadapi persalinan dan tidak menyebabkan depresi pernafasan pada bayi yang dilahirkan (Makfuah, 2014).

Pijat dan sentuhan membantu ibu lebih rileks dan nyaman yang dilakukan selama 20 menit setiap jam selama tahapan persalinan, karena pijat merangsang tubuh melepaskan senyawa endorphin yang merupakan pereda sakit alami dan menciptakan perasaan nyaman. Metode ini juga dapat meningkatkan stamina untuk mengatasi rasa nyeri (Pastuty, 2012).

Penelitian ini sesuai dengan pendapat yang disimpulkan oleh Sri Rejeki (2013), bahwa rentang nyeri yang sebelum dilakukannya suatu tindakan adalah 9-10 sebanyak 13 responden $(54,2 \%)$, pada skala 7-8 sebanyak 11 responden $(45,8 \%)$. Hal ini dapat diartikan bahwa nyeri yang paling banyak dialami ibu bersalin sebelum dilakukannya tindakan merupakan neri berat hingga nyeri tidak tertahankan. Setelah dilakukannya Teknik Massage Back-Effleurage terjadi penurunan nyeri berat menjadi nyeri sedang sebanyak 18 responden (75\%) pada skala 3-6. Oleh sebab itu, dapat dilihat langsung oleh penelitian dimana terjadi pengurangan rasa nyeri persalinan.

\section{KESIMPULAN}

Berdasarkan hasil uji Statistic (Uji Paired Sample T Test) dengan tingkat kepercayaan 95\% diperoleh nilai $p=0,000$ dimana nilai tersebut lebih kecil dari $0,05(p<a)$, maka Ho ditolak dan $\mathrm{Ha}$ diterima sehingga dapat disimpulkan ada pengaruh yang signifikan antara Teknik Massage Back-Effleurage terhadap pengurangan rasa nyeri persalinan Kala I.

\section{DAFTAR PUSTAKA}

Andarmoyo, Sulistyo. 2013. Konsep Dan Proses Keperawatan Nyeri. Ar-Ruza Media. Jogjakarta. 


\begin{tabular}{c|c|c}
\hline $\begin{array}{c}\text { Jurnal Penelitian Keperawatan } \\
\text { Medik }\end{array}$ & Vol. 2 No. 1 & Edition: May - October 2019 \\
\hline & $\frac{\text { http://ejournal.delihusada.ac.id/index.php/JPKM }}{\text { Revepted: 31 October 2019 }}$ & Acced: 28 October 2019 \\
\hline Received: 16 October 2019 & Revised & \\
\hline
\end{tabular}

Asrinah, dkk. 2017. Asuhan Kebidanan Masa Persalinan. Yogyakarta: Graha Ilmu.

Avilia. 2016. Pemberian Teknik Deep Back Massage terhadap Penurunan Nyeri Pada Asuhan Keperawatan pada Persalinan kala I fase aktif di ruang bersalin puskesmas Sibella. Surakarta. STIKES Kusuma Husada.

Cepeda, G.N. 2013. Asuhan Kebidanan Persalinan. EGC. Jakarta.

Dinkes Provinsi Jawa Tengah. 2015. Profil Kesehatan Provinsi Jawa Tengah.

Dinkes Provinsi Sumatera Utara. 2015. Profil Kesehatan Provinsi Sumatera Utara

Hutagalung, Runggu. 2012. Lama Persalinan. Jakarta: EGC.

http://takiya10.com/2012/04/lamapersalinan.html. Diakses tanggal 4 April 2019.

Icesmi Sukarni K. 2017. Kehamilan, Persalinan dan Nifas. Yogyakarta: Nuha Medika.

Judha, dkk. 2012. Teori Pengukuran Nyeri dan Nyeri Persalinan. Nuha Medika. Yogyakarta.

Kemenkes RI. 2015. Profil Kesehatan Indonesia.

Keputusan Menteri Kesehatan RI Nomor 369/MENKES/SK/III/2007. Standar Profesi Bidan. Jakarta : Kepmenkes RI. Diakses: https://ejurnal.akperpantikosala.ac.id.

Kuswanti, dkk. 2013. Askeb II Persalinan. Penerbit Pustaka Pelajar (Anggota IKAPI). Yogyakarta.

Lestari. 2012. Pengaruh Deep Back Massage Terhadap Penurunan Nyeri Persalinan Kala I Fase Aktif dan Kecepatan Pembukaan pada Ibu Bersalin. Surabaya. STIKES Kusuma Husada

Makfuah, S. 2014. Standar Operasional Prosedur Effleurage Massage. Diakses: 04 April 2019. (http://id.Scribd.com).

Mayunani, Anik. 2013. Nyeri dalam Persalinan Teknik dan Cara Penanggulangannya. Jakarta, TIM

Notoadmodjo,N. 2013. Metodologi Penelitian Kesehatan. Jakarta: Rineka Cipta.

Noviyanti. 2016. Pengaruh Terapi Pijat Terhadap Pengurangan Nyeri Persalinan Kala I Fase
Aktif pada Ibu Bersalin. Jakarta, TIM. https://ejurnal.akperpantikosala. (04 April 2019).

Pastuty, Rosyati. 2012. Buku Saku Asuhan Kebidanan Ibu Bersalin. Jakarta: Penerbit Buku Kedokteran EGC.

PERMENKES No. 97 Tahun 2014. Pelayanan Kesehatan Masa Sebelum Hamil, Masa Hamil, Persalinan, dan Masa Sesudah Melahirkan, Penyelenggaraan Pelayanan Kontrasepsi Serta Pelayanan Kesehatan Seksual.

Potter, Patricia A. \& Perry, Griffin Anne. 2015. Buku Ajar Fundamental Keperawatan: Konsep, Proses Dan Praktek Edisi 4. Alih bahasa : Komlasi, Penata. EGC. Jakarta.

Reeder, S. J., Martin, L.I., \& Griffin, D. K. 2011. Maternity nursing : family, newborn, and women's health care. Alih bahasa, Afiyanti, Y., et al. Jakarta : EGC. Jurnal Keperawatan Maternitas. Volume : 1, No. 2, November 2013; 124-133

Sri Rejeki, Hartati T, Khayati N. Nyeri Persalinan Kala I melalui Praktek Counter-Pressure diRSUD Soewondo Kendal. Jurnal Keperawatan Maternitas Volume 2, No. 2, November 2014; 127-135

Survey Demografis Kesehatan Indonesia (SDKI). 2014. Data Angka Kematian Ibu (AKI) di Indonesia.

Suryamin. 2014. Kajian Indikator Lintas Sektor Sustainable Development Goals (SDGs). Jakarta. Badan Pusat Statistik.

WHO (World Health Organization). 2015. Data Angka Kematian Ibu Hamil. http://harianpelita.pelitaonline.com/cetak/ 2013/09/30/data-angka-kematian-ibuhamil-menurut-who. Diakses tanggal 4 April 2019.

Yeyeh, dkk. 2014. Asuhan Kebidanan II Persalinan. Jakarta: Trans Info Media.

Yuliatun, L. 2016. Penanganan Nyeri Persalinan Dengan Metode Nonfarmakologi. Bayu Media Publishing, Malang. 